\title{
The spaces of the self
}

\author{
Christopher Pratt \\ Curated by Josée Drouin-Brisebois, \\ Assistant Curator of Contemporary Art \\ National Gallery of Canada \\ Ottawa, Ont. \\ Sept. 30, 2005 - Jan. 82006
}

I n October 1953, Lawren P. Harris, war artist, son of the Group of Seven painter Lawren S. Harris and Director of the School of Fine and Applied Arts at New Brunswick's Mount Allison University, did the art world an immense service. He wrote to the father of a young student from Newfoundland to persuade him that his son ought to give up plans for a career in medicine and study art instead:

As I have told Christopher, the art profession is not nearly as lucrative as the medical profession, and that it is no secret that many artists have a rather difficult time in making a living - but as $\stackrel{\infty}{\circ}$ in all professions, those who are well above the ô average are spared the troubles which the mediocre have to face; as the saying goes, "there is always lots of room at the top."

More than 50 years later, Christopher Pratt has been enjoying that room at the top with a major exhibition the first on this scale since $1985-$ mounted in honour of his 7oth birthday at the National Gallery of Canada.

Perhaps the most striking aspect of this exhibition of 60 paintings, largely from the last 20 years, is their manner of simultaneously signifying and contradicting an absence. A first glance at many of these canvases impresses the viewer with their emptiness. Form, space, shadow, light, smooth surface and hard edge give the viewer plenty to engage with, but it is striking how unpeopled these paintings are. A cluster of figure studies is included in the show, but there is even less human narrative in these formal exercises than in other works where a person is present by implication. Dresser and Dark Window (I98I), for example, gives us not a woman at a dressing table, but a bare piece of furniture over which a round mirror and the yawning reflection of a black window disturbingly preside; in The Visitor (1977) an unseen guest is implied by a chest of drawers, a drawn window-blind and an undergarment drying on a radiator. In Pratt's spartan interiors, beds are empty and have not been slept in (Basement with Two Beds,
I995); walls are bare, aside from angular patches of light falling from a window, or a shadow where a painting once had been (My Rooms, 1995).

The recollection of presence in absence extends beyond Pratt's domestic subjects. The abandoned way of life of Labrador whalers is suggested by empty sleeping bunks (Whaling Station, I983); the life of an outport town deserted during the Resettlement is evoked with empty shelves beside a window (Shop on an Island, I969); the prowling of a cat in a factory yard is marked by pawprints in a drift of snow (Crab Plant with Cat Tracks, 2002).

Among the ephemera displayed with this exhibition are some working notes and sketches apparently related to The Americans: Off Base Housing (I999). A few figures appear in the sketches, but at the bottom of an accompanying note Pratt has written "Danger: All that hotel/motel contemporary sociology junk," warning himself against letting the wrong narrative intrude. Human inhabitants do not appear in the finished canvas, but we can make some guesses about their lives. The trailers are temporary houses, their arrangement confining;

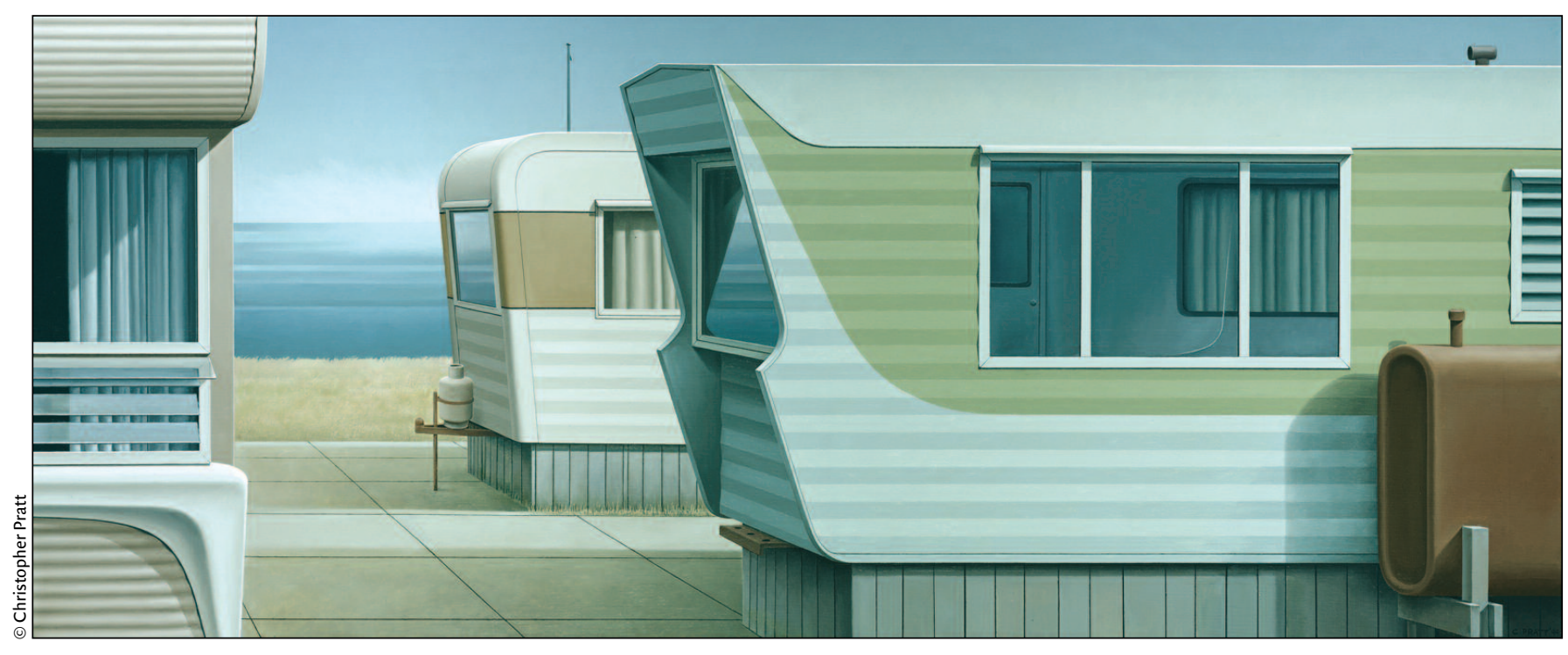

Christopher Pratt. The Americans: Off Base Housing, 1999. Oil on canvas. $71.1 \mathrm{~cm}$ x $127.7 \mathrm{~cm}$. Collection of Ron Joyce. 


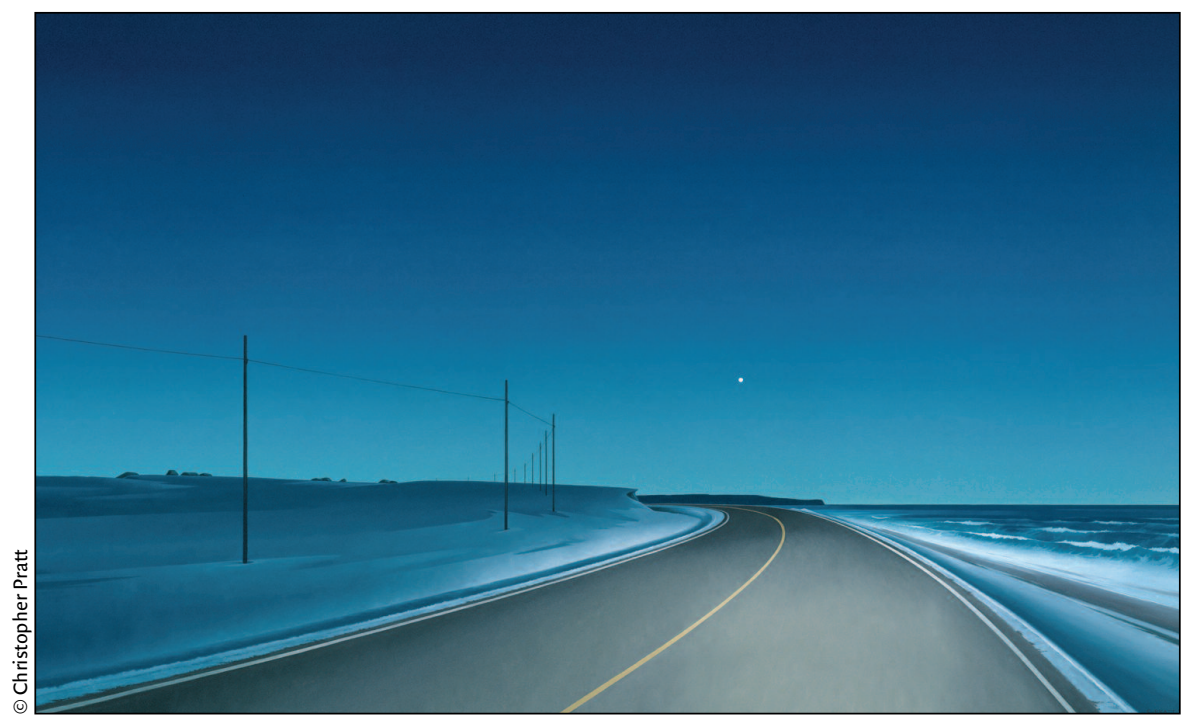

Christopher Pratt. Driving to Venus: From Eddies Cove East, 2000. Oil on hardboard. $101.6 \mathrm{~cm} \times 165.1 \mathrm{~cm}$. Shaw Communications Inc.

beyond them is a narrow glimpse of ocean. Curtained windows conceal domestic interiors, reflecting back a banal sameness from the viewer's side. But we also notice that what is reflected is precisely what the viewer does not see from his or her vantage point. Pratt's rendering appears factual and objective, but that reflection in the window takes note of a subjective side. What we see always reflects, in part, ourselves.

This confrontation with the viewing self is not confined to reflective surfaces in Pratt's paintings. When he turns to exterior views - the sweep of ocean beyond a window, the curve of windswept highway, a dwelling in swirling snow - Pratt challenges us with a psychological landscape most of all. The "driving to Venus" paintings show us a hypnotic road, the alluring Evening Star, the mystery of approaching headlights or a curve ahead, and we are transported to an inner space, as in the quietly terrifying Pedestrian Tunnel (I99I), in which an underground walkway dips down and disappears from view. There is no end, it seems, to the vortex of self-reflection, but at least Pratt gives us order, precision and mathematical calculation to cling to. There is no expressionistic hysteria here, despite a claustrophobic overlay of dread.

Those who are automatically de- pressed by emptiness or, unlike Pratt, have little tolerance for solitude, may find this body of work not merely austere but distinctly bleak. Some may be frustrated by Pratt's liking for compositions that thwart our view. March Night (1976) confronts us with a wall of clapboard siding that occupies almost the entire canvas with no declaration of what stands before, beside, or behind - aside from a narrow escape route for the eye, an empty space on the right through which a treeline is silhouetted in the far distance. In other

\section{Vampire}

CBC, lytes, glucose, BUN, creatinine, INR/PTT, liver function tests,

cultures $\times 2$,

toxicology screen,

calcium, magnesium, TSH,

cardiac enzymes,

blood gases.

After all the blood I've sucked from him

은 you'd think l'd have a better grip on his soul.

\section{Gwynedd Pickett}

Department of Neurosurgery

Hope Hospital

Salford, Lancs., UK canvases, windows are placed too high to see through, giving us a cruel idea of a view, and through glass doorways we see fog or shadows merely. On the other hand, these devices of containment seem to express a desire for open space, a longing for possibility. And it seems that these are not unattainable desires: some of Pratt's windows open onto a serene and limitless ocean or an indigo, starlit sky.

Although Pratt's art is absolutely imbued with a sense of place, it does not yield to sentimentalism or cliché; this is a contemporary, unidealized Newfoundland that he presents. There are no folkloric dories here, but gleaming industrial boats, along with warehouses, suburbs, highways, and a hydro station beside which a captured river roils. There are references to the past, but elegy is restrained. The viewer confronts the disappointments of postConfederation Newfoundland in a stripped-down form, without rhetoric or high emotion. Even in an overtly political painting, the recent Winter at Whiteway (2004), the painfully emblematic objects depicted on a wharf an oil drum, life buoy, cod table, and the shreds of a Canadian flag - are, Pratt claims, just as he found them on a trip to Trinity Bay. ${ }^{2}$

Beneath the reticent surface of these paintings is a passion for Newfoundland and a profound understanding of

Stat please on Mr. Whatsisname in stretcher 5. 
its contradictions: between the infinity of nature and the smaller, necessitous, human sphere; between the emptiness of highways and the social connections they signify; between the acceptance of modernity and the loss of insular identity. And there is, perhaps above all, the paradox of beauty in austerity - an attribute of Newfoundland's land-and seascape and of Pratt's art. His elimination of detail and flat application of oils manages to achieve a luminous patina, a convincing glaze of light that makes us feel that we are seeing something truthful and real.

Pratt considers a painting finished when that light finally seems "right" and he feels a "thirty-second rush." Pratt's ability to bring the viewer to the same conviction speaks not only to his impeccable technique but also to a precise and honest understanding and the unflinching analysis of his gaze.

\section{Anne Marie Todkill \\ CMAJ}

\section{REFERENCES}

I. Harris LS. Letter to John (Jack) Kerr Pratt. I6 Oct I953 [displayed with exhibit].

2. Dytnerska B. Life is not a rehearsal [interview with Christopher Pratt]. In: Drouin-Brisebois J. Christopher Pratt: All my own work. Ottawa: National Gallery of Canada; 2005

3. Drouin-Brisebois J. Christopher Pratt in the political landscape. In: Drouin-Brisebois J. Christopher Pratt: All my own work. Ottawa: National Gallery of Canada; 2005

\section{One thousand words}

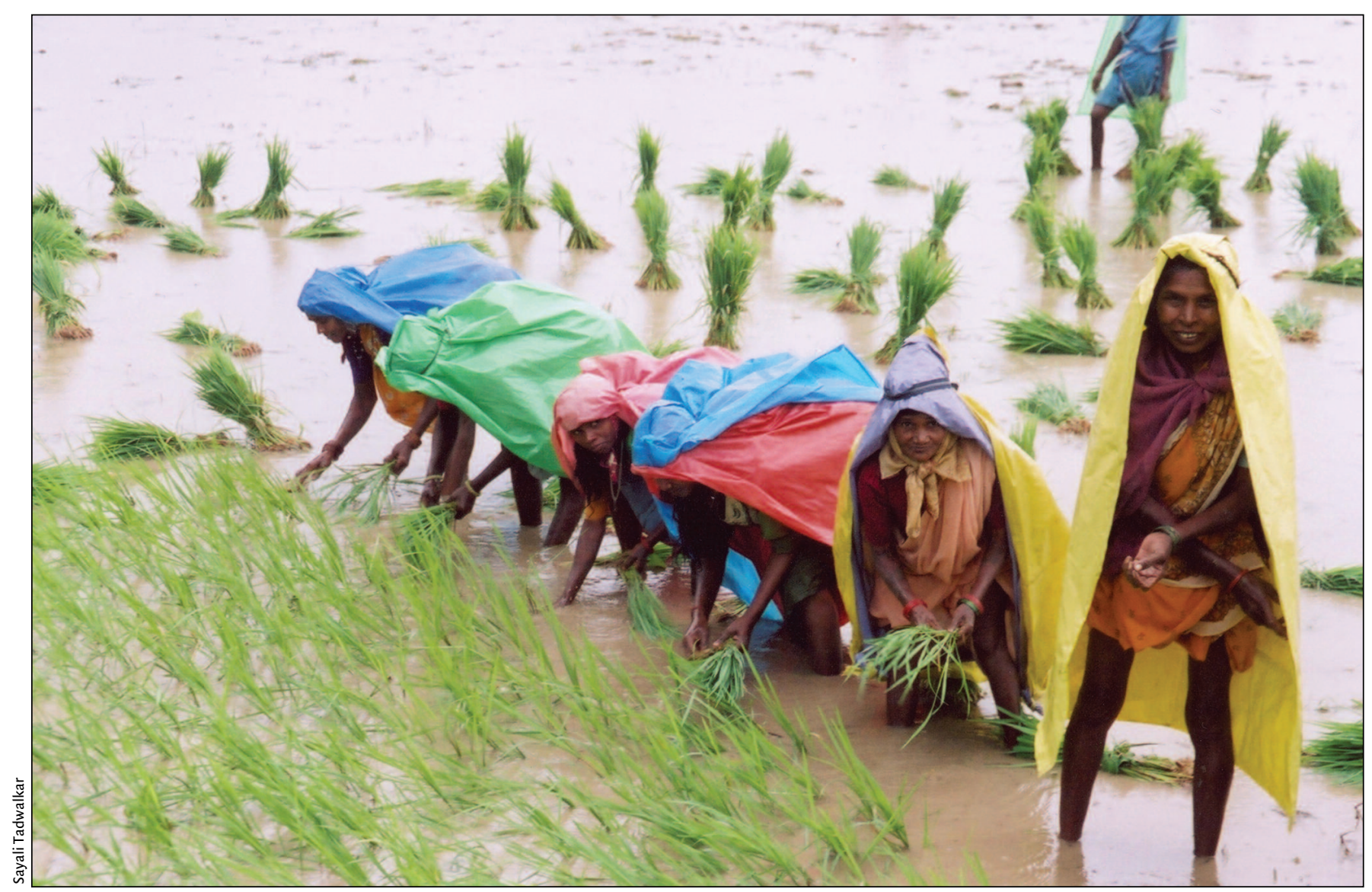

The belated grains of sustenance. This photograph, taken by first-year McMaster University medical student Sayali Tadwalkar during an 8-week clinical elective, was among the entries exhibited at McMaster's International Women's and Children's Health Symposium last fall. CMAJ has selected 3 for publication; the first appeared in our Dec. 6, 2005, issue (CMAJ 2005;173:1514). This photograph captures the repetitiveness, hardship and social bonds of manual farm labour, and leaves us pondering the health consequences of these women's working conditions. The photographer writes: "In the district of Gadchiroli, India, farming is the main profession of the people, and rice is the primary agricultural product. Regardless of pouring rain or scorching sun, the women of the nearby villages spend entire days manually planting rice seedlings in the hope that the crop will be productive. The women in this picture are wearing protection on their heads from the rain overhead, while their feet are submerged for hours under water as they work to finish planting all the bundles that are seen in the background into orderly rows. Depending on the whims of Mother Nature, their labour will not bear fruit until several months later." 